Article

\title{
Effects of pretreatment on performance and structure of Ni-Co bimetallic catalyst for biogas reforming to hydrogen
}

\author{
Jian Zhao a,b, Wei Zhou b,c,*, Jianxin Ma a,b,c \\ a School of Resource and Environmental Engineering, East China University of Science and Technology, Shanghai 200237, China \\ ${ }^{\mathrm{b}}$ Clean Energy Automotive Engineering Center, Tongji University, Shanghai 201804, China \\ ' School of Automotive Studies, Tongji University, Shanghai 201804, China
}

\section{A R T I C L E I N F O}

\section{Article history:}

Received 24 April 2013

Accepted 19 June 2013

Published 20 October 2013

Keywords:

Pretreatment

Nickel-cobalt catalyst

Biogas reforming

Carbon formation resistance

Hydrogen production

\begin{abstract}
A B S T R A C T
$\mathrm{Ni}$-Co bimetallic catalysts supported on $\gamma-\mathrm{Al}_{2} \mathrm{O}_{3}$ pellets for biogas reforming to hydrogen were successfully prepared using the excessive impregnation method. The effects of pretreatment on the catalytic performance were investigated in a fixed-bed vertical quartz reactor under conditions of $850{ }^{\circ} \mathrm{C}, 0.1 \mathrm{MPa}$, and a gas hourly space velocity of $6000 \mathrm{~mL} \mathrm{gat}^{-1} \mathrm{~h}^{-1}$ (4 g of catalyst, $2.5-3.5 \mathrm{~mm}$ ). The samples were characterized using X-ray diffraction, transmission electron microscopy, thermogravimetry coupled to differential scanning calorimetry, and emission scanning electron microscopy with energy-dispersive X-ray spectroscopy. The results showed that the catalyst pretreated with both $\mathrm{H}_{2}$ and $\mathrm{CO}_{2}$ showed higher activity, and basically eliminated the long induction period of the biogas reforming reaction, compared with the catalyst pretreated with only $\mathrm{H}_{2}$. In a $511 \mathrm{~h}$ stability test, the catalyst pretreated with both $\mathrm{H}_{2}$ and $\mathrm{CO}_{2}$ exhibited excellent stability, with a very low carbon deposition rate, ca. $0.2 \mathrm{mg} \mathrm{gat}^{-1} \mathrm{~h}^{-1}$. The average conversion of $\mathrm{CH}_{4}$ and $\mathrm{CO}_{2}$, selectivity for $\mathrm{H}_{2}$ and $\mathrm{CO}$, and ratio of $\mathrm{H}_{2} / \mathrm{CO}$ were $96 \%, 97 \%, 98 \%, 99 \%$, and 0.98 , respectively. The characterization results showed that the catalyst pretreated with both $\mathrm{H}_{2}$ and $\mathrm{CO}_{2}$ exhibited higher carbon formation resistance and better anti-sintering performance during reactions; this resulted in smaller metal particles and thus enhanced the stability of the catalyst. This new pretreatment route is very promising for enhancing the performance of biogas reforming catalysts.
\end{abstract}

(c) 2013, Dalian Institute of Chemical Physics, Chinese Academy of Sciences. Published by Elsevier B.V. All rights reserved.

\section{Introduction}

Hydrogen, which is a clean and sustainable energy carrier, is emerging as an alternative to conventional fossil fuels. The use of fuel cells is projected to increase dramatically in the future. With thousands of 1-100 kW automotive units and several multi-megawatt stationary units coming into operation, $\mathrm{H}_{2}$ demand will surge. However, most $\mathrm{H}_{2}$ in the near-to-medium term will be produced by steam reforming of unsustainable fossil fuels, primarily natural gas $\left(\mathrm{CH}_{4}+\mathrm{H}_{2} \mathrm{O} \rightarrow \mathrm{CO}+3 \mathrm{H}_{2}\right)$ [1]. In the long run, more production routes need to be developed.

Biogas, of which the main components are the principal greenhouse gases (GHG), $\mathrm{CH}_{4}$ and $\mathrm{CO}_{2}$, is a clean and environmentally friendly fuel, which is typically generated by anaerobic degradation of biomass. Nowadays, landfill gas represents $80 \%$ of world biogas production [2]. $\mathrm{H}_{2}$ production via biogas reforming, which is in essence carbon dioxide reforming of methane ( $\mathrm{CDRM}, \mathrm{CH}_{4}+\mathrm{CO}_{2} \rightarrow 2 \mathrm{CO}+2 \mathrm{H}_{2}$ ), is an attractive alternative method of using $\mathrm{CH}_{4}$ and $\mathrm{CO}_{2}$ simultaneously [3-9], contributing to the reduction of GHG emissions to the envi-

\footnotetext{
*Corresponding author. Tel: +86-21-69583720; Fax: +86-21-69583850; E-mail: wzhou@tongji.edu.cn This work was supported by the Ministry of Science and Technology International Cooperation Program (2010DFA64080) and the National High Technology Research and Development Program of China (863 Program, 2011AA11A275). 
ronment and offering distributed energy production at the same time.

However, no commercial catalyst is available for CDRM, the main reason being the formation of carbon via methane decomposition (MD, $\mathrm{CH}_{4} \rightarrow \mathrm{C}+2 \mathrm{H}_{2}$ ) and $\mathrm{CO}$ disproportionation $\left(2 \mathrm{CO} \rightarrow \mathrm{C}+2 \mathrm{CO}_{2}\right)$, which are favored under CDRM conditions [10]. Rostrup-Nielsen [11] demonstrated that carbon formation could not be avoided with $\mathrm{CO}_{2} / \mathrm{CH}_{4}$ ratio of $1: 1$ over $\mathrm{Ni}$ catalysts, and two kinds of carbon are often observed in CDRM [12]: filamentous (whisker-like) carbon produced by adsorbed carbon atoms, derived mainly from $\mathrm{CH}_{4}$ decomposition, and encapsulating hydrocarbon films (shell-like) formed by polymerization.

Pretreatment is an effective way of improving catalytic performance $[13,14]$. Furthermore, there is a current interest in solving the problem of activating $\mathrm{CH}_{4}$ and $\mathrm{CO}_{2}$, which are rather inert. The surface occupancies of the Ni surface in CDRM dedicated to $\mathrm{CH}_{4}$ and $\mathrm{CO}_{2}$ activation are $94 \%$ and $6 \%$, respectively [15]. It is believed that $\mathrm{CH}_{4}$ decomposition is the initial step in the reforming reaction, resulting from $\mathrm{MD}$ on the metal surface. The activation of $\mathrm{CO}_{2}$ occurs on the active sites $\left(\mathrm{CO}_{2}+\mathrm{S} \rightarrow\right.$ $\mathrm{S}-\mathrm{CO}_{2}$ ), and the primary step of carbon species removal can be expressed by the reaction $\mathrm{S}-\mathrm{CO}_{2}+\mathrm{C} \rightarrow 2 \mathrm{CO}+\mathrm{S}$, where $\mathrm{S}$ represents the active sites. The large difference between surface occupancies would result in insufficient activation of $\mathrm{CO}_{2}$, in which case the rate of MD is more rapid than that of the reaction $\mathrm{CO}_{2}+\mathrm{S} \rightarrow \mathrm{S}-\mathrm{CO}_{2}$, so the reaction $\mathrm{S}-\mathrm{CO}_{2}+\mathrm{C} \rightarrow 2 \mathrm{CO}+\mathrm{S}$ is forbidden or retarded, leading to carbon formation [11].

To address this problem, routes that could increase the occupancy of $\mathrm{CO}_{2}$ would be effective. However, pretreatment with only $\mathrm{CO}_{2}$ has no obvious influence on the catalytic activity [16]. Solymosi [17] reported that the presence of surface metallic Ni can dramatically increase the adsorption and reactivity of $\mathrm{CO}_{2}$, which indicates that catalysts should first be reduced to transform the active metals from an oxide state to a metallic state before they are treated with $\mathrm{CO}_{2}$. In view of the above, a new pretreatment route was designed, in which the catalyst was pretreated with $\mathrm{H}_{2}$ and then with $\mathrm{CO}_{2}$ to maximize the adsorption, reactivity, and occupancy of $\mathrm{CO}_{2}$ on the catalyst. The activity and stability of the catalyst for biogas reforming were investigated using a series of catalytic tests in a fixed-bed vertical quartz reactor and compared with those of a catalyst prepared using the traditional pretreatment with only $\mathrm{H}_{2}$. The impact of the pretreatment route was investigated using X-ray diffraction (XRD), transmission electron microscopy (TEM), thermogravimetry coupled with differential scanning calorimetry (TG-DSC), and scanning electron microscopy with energy-dispersive X-ray spectroscopy (SEM-EDX) in terms of the crystal structure, morphology, carbon deposition resistance, and anti-sintering ability.

\section{Experimental}

\subsection{Catalyst preparation}

$\mathrm{Ni}-\mathrm{Co} / \mathrm{La}_{2} \mathrm{O}_{3}-\mathrm{Al}_{2} \mathrm{O}_{3}$ bimetallic catalysts were prepared by excessive impregnation of $\gamma-\mathrm{Al}_{2} \mathrm{O}_{3}$ pellets $(2.5-3.5 \mathrm{~nm})$ with an aqueous solution of $\mathrm{Ni}\left(\mathrm{NO}_{3}\right)_{2} \cdot 6 \mathrm{H}_{2} \mathrm{O}, \mathrm{Co}\left(\mathrm{NO}_{3}\right)_{2} \cdot 6 \mathrm{H}_{2} \mathrm{O}$, and $\mathrm{La}\left(\mathrm{NO}_{3}\right)_{3} \cdot 6 \mathrm{H}_{2} \mathrm{O}$. The samples were dried at $120{ }^{\circ} \mathrm{C}$ for $6 \mathrm{~h}$ and then calcined at $850{ }^{\circ} \mathrm{C}$ for $2 \mathrm{~h}$ in air. The prepared samples contained $7 \mathrm{wt} \% \mathrm{Ni}, 3 \mathrm{wt} \% \mathrm{Co}$, and $6 \mathrm{wt} \% \mathrm{La}_{2} \mathrm{O}_{3}$ promoter.

\subsection{Catalyst characterization}

XRD was conducted using a D/max 2550 (Rigaku) diffractometer with $\mathrm{Cu}-K_{\alpha}$ radiation $(\lambda=0.154056 \mathrm{~nm})$, operated at $40 \mathrm{kV}$ and $100 \mathrm{~mA}$, to detect the crystalline phases of the catalyst. The diffraction patterns were recorded in the $2 \theta$ range $10^{\circ}-100^{\circ}$ with a scanning rate of $0.02^{\circ} / \mathrm{min}$.

TEM was performed using a JEM-2010 (Hitachi) microscope operated at $200 \mathrm{kV}$ to investigate the morphology of the carbon deposits on the spent catalyst, and the metal particle size and distribution of the used catalyst.

The carbon deposits were analyzed using TG (STA449C, NETSCHZ) coupled with DSC. About $10 \mathrm{mg}$ of used catalyst was placed in an alumina crucible and heated from room temperature to $1000{ }^{\circ} \mathrm{C}$ at a rate of $10{ }^{\circ} \mathrm{C} / \mathrm{min}$ in a mixture of $5 \% \mathrm{O}_{2} / \mathrm{N}_{2}$ at a flow rate of $120 \mathrm{~mL} / \mathrm{min}$; an empty alumina crucible was used as a reference.

The morphology and element distribution of the catalysts were investigated using SEM (SIRION 200, FEI Company) operated at $5.0 \mathrm{kV}$, and EDX (INCA, Oxford Company) with a sensitivity of $130 \mathrm{eV}$.

\subsection{Catalyst pretreatment and catalytic reactions}

The catalyst pretreatment and evaluation were carried out under atmospheric pressure in a fixed-bed vertical quartz reactor (i.d. $25 \mathrm{~mm}$ ) packed with $4 \mathrm{~g}$ of catalyst. In the traditional pretreatment route, the catalyst was reduced in situ for $2 \mathrm{~h}$ in pure $\mathrm{H}_{2}$ at a flow rate of $30 \mathrm{~mL} / \mathrm{min}$ at $700{ }^{\circ} \mathrm{C}$; the catalyst pretreated using this route was designated Cat-H. In the new route, after the traditional pretreatment, the catalyst was further pretreated in situ for $2 \mathrm{~h}$ in pure $\mathrm{CO}_{2}$ at a flow rate of $200 \mathrm{~mL} / \mathrm{min}$ at $850{ }^{\circ} \mathrm{C}$; the catalyst pretreated using this new route was designated Cat-HCD. The temperature at the center of the catalyst bed was measured using a K-type thermocouple thermometer with a stainless-steel thermocouple well. The gaseous products leaving the reactor passed through an ice-cold trap to remove water formed during the reaction. The feed flow rates were controlled using mass flow controllers (Alicat Company), and the exhaust flow rate was measured using a primary flow calibrator (Gilian, Sensidyne Company). The concentrations of reactants and products were determined using an online gas chromatograph (GC; GC7890 II, Techcomp Company) equipped with a thermal conductivity detector (TCD) and a TDX-01 column of length $3 \mathrm{~m}$ and outer diameter $3 \mathrm{~mm}$. Ar was used as the carrier gas. The GC oven and TCD temperature were held at 150 and $180{ }^{\circ} \mathrm{C}$, respectively. The $\mathrm{CO}_{2}$ and $\mathrm{CH}_{4}$ conversion and selectivity for $\mathrm{H}_{2}$ and $\mathrm{CO}$ are defined as follows:

$$
\begin{gathered}
X\left(\mathrm{CH}_{4}\right)=\left(F_{\text {in }}\left(\mathrm{CH}_{4}\right)-F_{\text {out }}\left(\mathrm{CH}_{4}\right)\right) / F_{\text {in }}\left(\mathrm{CH}_{4}\right) \times 100 \% \\
X\left(\mathrm{CO}_{2}\right)=\left(F_{\text {in }}\left(\mathrm{CO}_{2}\right)-F_{\text {out }}\left(\mathrm{CO}_{2}\right)\right) / F_{\text {in }}\left(\mathrm{CO}_{2}\right) \times 100 \% \\
S\left(\mathrm{H}_{2}\right)=F\left(\mathrm{H}_{2}\right) /\left(2\left(F_{\text {in }}\left(\mathrm{CH}_{4}\right)-F_{\text {out }}\left(\mathrm{CH}_{4}\right)\right)\right) \times 100 \% \\
S(\mathrm{CO})=F(\mathrm{CO}) /\left(\left(F_{\text {in }}\left(\mathrm{CH}_{4}\right)-F_{\text {out }}\left(\mathrm{CH}_{4}\right)\right)+\left(F_{\text {in }}\left(\mathrm{CO}_{2}\right)-F_{\text {out }}\left(\mathrm{CO}_{2}\right)\right)\right) \times 100 \%
\end{gathered}
$$




$$
F_{i}=F_{\text {total }} \cdot \mathrm{c}_{i}
$$

where the subscripts in and out are inlet and outlet, respectively, $F_{i}$ is the flow rate of each reagent or product, $F_{\text {total }}$ represents the total flow rate of the gaseous effluent, and $c_{i}$ is the molar fraction of component $i$ in the gaseous effluent.

\section{Results and discussion}

\subsection{Catalytic activity}

Figure 1 shows the effects of the pretreatment route on the activity of the $\mathrm{Ni}-\mathrm{Co} / \mathrm{La}_{2} \mathrm{O}_{3}-\mathrm{Al}_{2} \mathrm{O}_{3}$ catalyst. The results show that the new route significantly enhances the conversion of $\mathrm{CH}_{4}$ and $\mathrm{CO}_{2}$. After reaction for $27 \mathrm{~h}$, the $\mathrm{CH}_{4}$ and $\mathrm{CO}_{2}$ conversion increased from $88 \%$ and $96 \%$ to $95 \%$ and $99 \%$, respectively. The $\mathrm{CH}_{4}$ and $\mathrm{CO}_{2}$ conversion using Cat-H underwent an induction period of about $25 \mathrm{~h}$ and then attained a steady state. During the induction period, the amount and particle size of active metal, the carbon deposition and gasification, and the textural properties of the samples were continuously changing and regulating until relative stability was reached, and deposition of superficial carbonaceous species on the surface metal crystallites established an equilibrium [18,19]. However, Cat-HCD exhibited higher initial catalytic activity and no induction period. It is known that $\mathrm{CO}_{2}$ can be adsorbed on a $\mathrm{Ni}$ metal surface from the gas phase [20]. Based on the literature [6,16,21], the mechanism for the new pretreatment and subsequent CDRM on the catalyst are presented in Fig. 2. First, $\mathrm{CO}_{2}$ chemisorption takes place on the Cat-HCD metal surface. Second, the adsorbed $\mathrm{CO}_{2}$ decomposes to $\mathrm{CO}$ and $\mathrm{O}$ species during CDRM. The $\mathrm{O}$ species can react with the accumulated carbon on the Ni crystallites at the beginning of the reaction to produce $\mathrm{CO}$, thus preventing carbon from covering the $\mathrm{Ni}$ crystallites, and consequently significantly improving the activity of the catalyst. Furthermore, it can be deduced that the ability of Cat-HCD to resist carbon deposition is also enhanced.

\subsection{Characterization results of spent catalyst}

\subsubsection{XRD results}

Figure 3 shows the XRD patterns of the catalyst before and after reaction. In all the samples, the diffraction peaks from $\gamma-\mathrm{Al}_{2} \mathrm{O}_{3}$ can be observed. Before reaction (Fig. 3(a)), a diffraction peak related to $\mathrm{Ni}^{2+} / \mathrm{Co}^{2+}(\mathrm{NiO} / \mathrm{CoO})$ is observed in the fresh catalyst, but the intensity of the diffraction peaks related to $\mathrm{Ni}^{2+} / \mathrm{Co}^{2+}$ in Cat-H becomes weaker, indicating that $\mathrm{Ni}^{2+} / \mathrm{Co}^{2+}$ is reduced to $\mathrm{Ni}^{0} / \mathrm{Co}^{0}$. In contrast, $\mathrm{Ni}^{0} / \mathrm{Co}^{0}$ is oxidized to

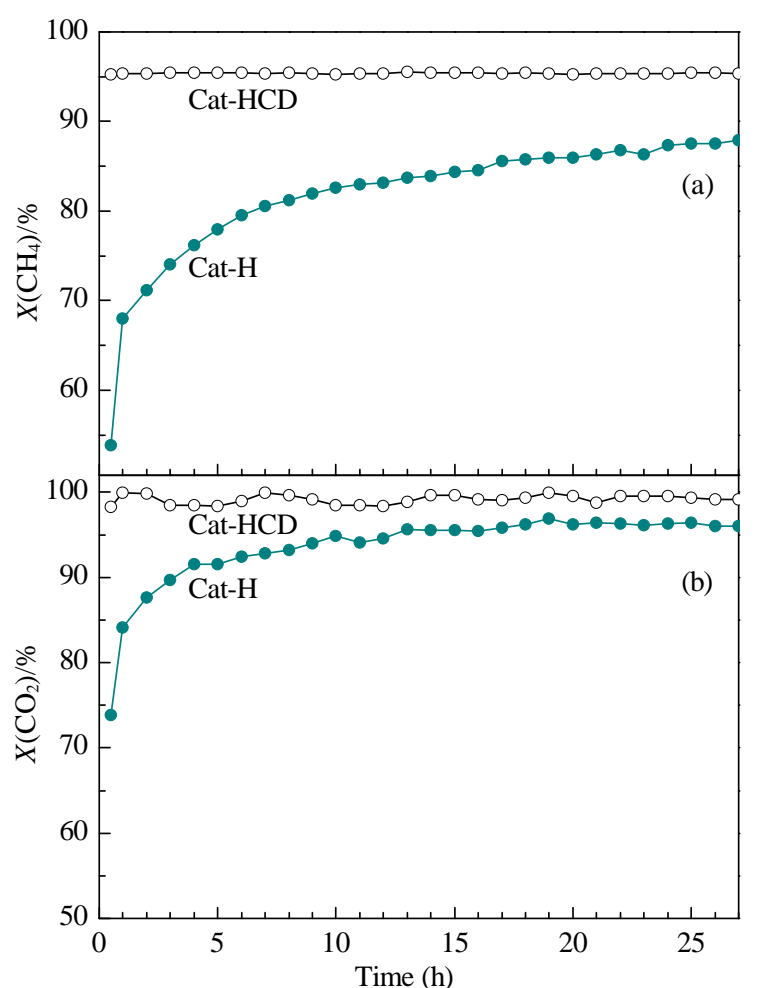

Fig. 1. Conversion of $\mathrm{CH}_{4}$ (a) and $\mathrm{CO}_{2}$ (b) vs time-on-stream over $\mathrm{Ni}-\mathrm{Co} / \mathrm{La}_{2} \mathrm{O}_{3}-\mathrm{Al}_{2} \mathrm{O}_{3}$ catalysts pretreated using different routes. Reaction condition: $850{ }^{\circ} \mathrm{C}, 0.1 \mathrm{MPa}$, gas hourly space velocity $=6000 \mathrm{~mL} \mathrm{~g}_{\mathrm{cat}}{ }^{-1}$ $\mathrm{h}^{-1}, \mathrm{CH}_{4} / \mathrm{CO}_{2}=1 / 1$. Cat- $\mathrm{H}: \mathrm{Ni}-\mathrm{Co} / \mathrm{La}_{2} \mathrm{O}_{3}-\mathrm{Al}_{2} \mathrm{O}_{3}$ catalyst pretreated using traditional route (reduced in situ for $2 \mathrm{~h}$ in pure $\mathrm{H}_{2}$ at a flow rate of 30 $\mathrm{mL} / \mathrm{min}$ at $700{ }^{\circ} \mathrm{C}$ ); Cat-HCD: $\mathrm{Ni}-\mathrm{Co} / \mathrm{La}_{2} \mathrm{O}_{3}-\mathrm{Al}_{2} \mathrm{O}_{3}$ catalyst pretreated using the new route (traditional pretreatment followed by pretreatment in situ for $2 \mathrm{~h}$ in pure $\mathrm{CO}_{2}$ at a flow rate of $200 \mathrm{~mL} / \mathrm{min}$ at $850{ }^{\circ} \mathrm{C}$ ).

$\mathrm{Ni}^{2+} / \mathrm{Co}^{2+}$ in Cat-HCD, which proves that the $\mathrm{CO}_{2}$ pretreatment tends to be an oxidation process. After reaction (Fig. 3(b)), the $\mathrm{Ni}^{2+} / \mathrm{Co}^{2+}$ signal is not obvious. This indicates that the CDRM reaction tends to be a reduction process [22] and $\mathrm{Ni}^{2+} / \mathrm{Co}^{2+}$ is again reduced to $\mathrm{Ni}^{0} / \mathrm{Co}^{0}$ at high temperature. Furthermore, the diffraction peak assigned to graphitic carbon (PDF 26-1080) at $2 \theta=26.5^{\circ}$ is observed for Cat- $\mathrm{H}$, but this diffraction peak is not obvious in Cat-HCD. The results proved that Cat-HCD can inhibit carbon deposition.

The particle size of the metallic $\mathrm{Ni}^{0} / \mathrm{Co}^{0}$ after the reaction, calculated using the Scherrer equation [23], is listed in Table 1. It can be seen that the metal particle size is of almost the same order of magnitude (15.3-17.0 nm), but the Cat-HCD particle size is smaller, which indicates that the new pretreatment can prevent the catalyst from sintering to some extent.

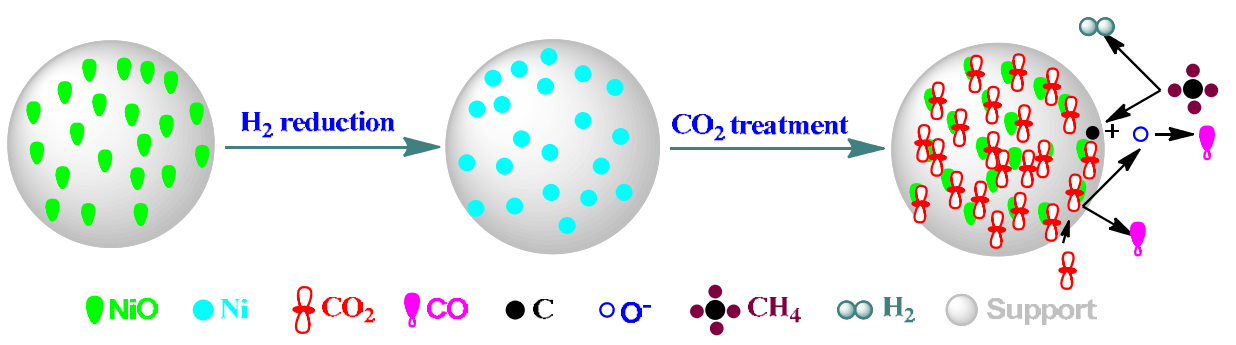

Fig. 2. Schematic diagram of mechanism of new pretreatment and subsequent CDRM. 


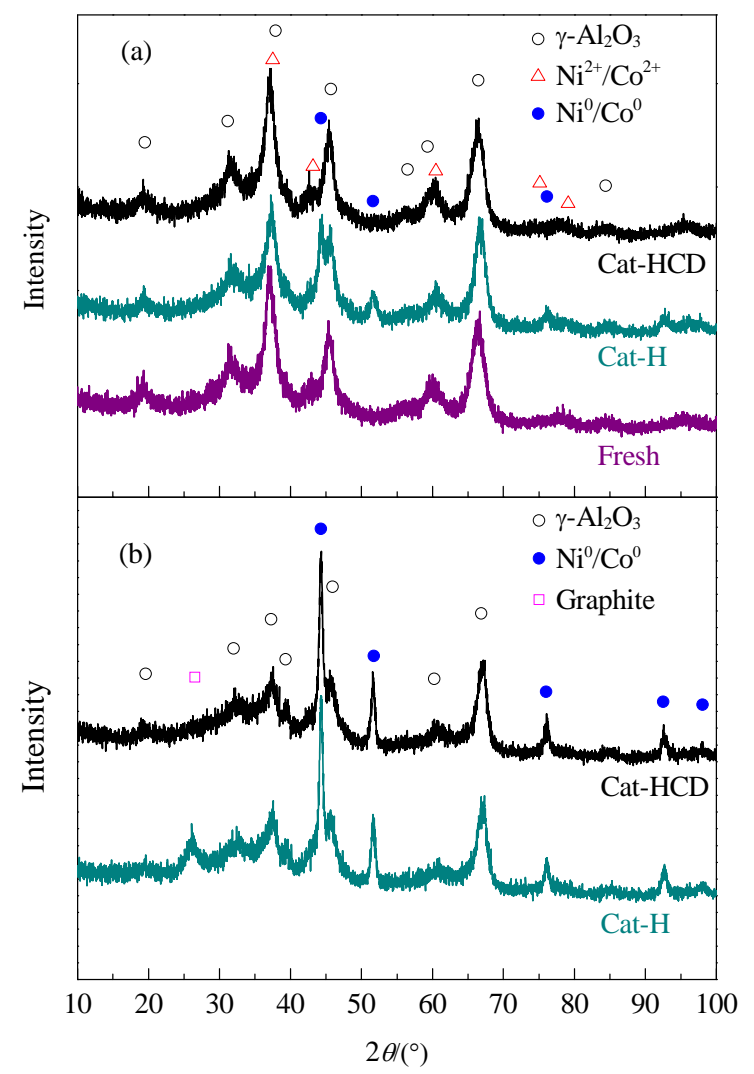

Fig. 3. XRD patterns of the $\mathrm{Ni}-\mathrm{Co} / \mathrm{La}_{2} \mathrm{O}_{3}-\mathrm{Al}_{2} \mathrm{O}_{3}$ catalyst samples pretreated using different routes. (a) Before reaction; (b) After reaction.

\section{Table 1}

Metal crystallite size $\left(D_{\mathrm{m}}\right)$ and average carbon deposition rates $\left(R_{\mathrm{c}}\right)$ of used catalyst after reaction for $27 \mathrm{~h}$ pretreated using different routes.

\begin{tabular}{lcc}
\hline Sample & $D_{\mathrm{m}} / \mathrm{nm}$ & $R_{\mathrm{c}} /\left(\mathrm{mg} \mathrm{g}_{\mathrm{cat}^{-1}} \mathrm{~h}^{-1}\right)$ \\
\hline Cat-H & 17.0 & 3.2 \\
Cat-HCD & 15.3 & 1.0 \\
\hline
\end{tabular}

\subsubsection{TEM results}

The images of spent catalyst samples and the metal particle size distributions are presented in Fig. 4. It is evident that metallic $\mathrm{Ni}$ or $\mathrm{Ni} / \mathrm{Co}$ particles are formed and well segregated from each other. From Fig. 4(a) and (b), it can be seen that the metal

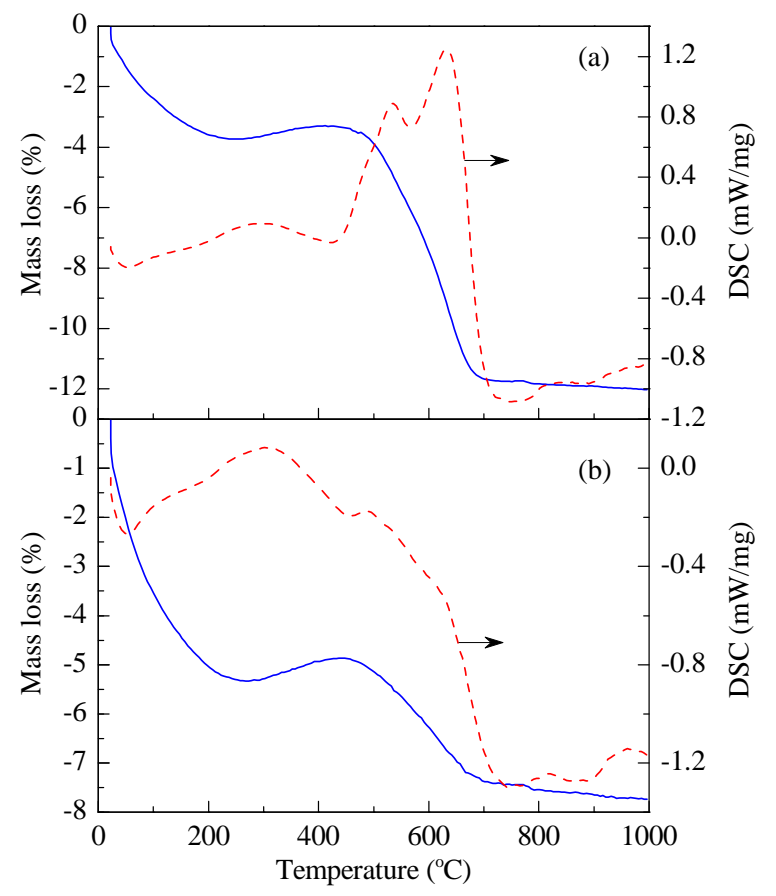

Fig. 5. TG-DSC curves of catalyst samples pretreated using different routes after reaction for $27 \mathrm{~h}$. (a) Cat-H; (b) Cat-HCD.

particle size of Cat-H is much larger than that of Cat-HCD. This is consistent with the XRD analysis results. The average metal particle size of Cat-HCD and Cat-H is 7.11 and $23.05 \mathrm{~nm}$, respectively, which illustrates that the new pretreatment route retards sintering of $\mathrm{Ni}^{0} / \mathrm{Co}^{0}$. In general, small metal particles can depress or decrease carbon formation [24,25].

\subsubsection{TG-DSC results}

Figure 5 shows the TG-DSC curves for the spent catalyst samples after reaction for $27 \mathrm{~h}$. The initial mass increment step occurs in the temperature range $300-450{ }^{\circ} \mathrm{C}$; this is ascribed to oxidation of the active $\mathrm{Ni}^{0} / \mathrm{Co}^{0}$ metal. Mass losses resulting from the removal of carbon occur at 550 and $651{ }^{\circ} \mathrm{C}$, and the DSC profiles have two distinguishable exothermic peaks. This indicates that there are at least two kinds of carbon deposited on the used catalyst. The first exothermic peak (at $550{ }^{\circ} \mathrm{C}$ ) is
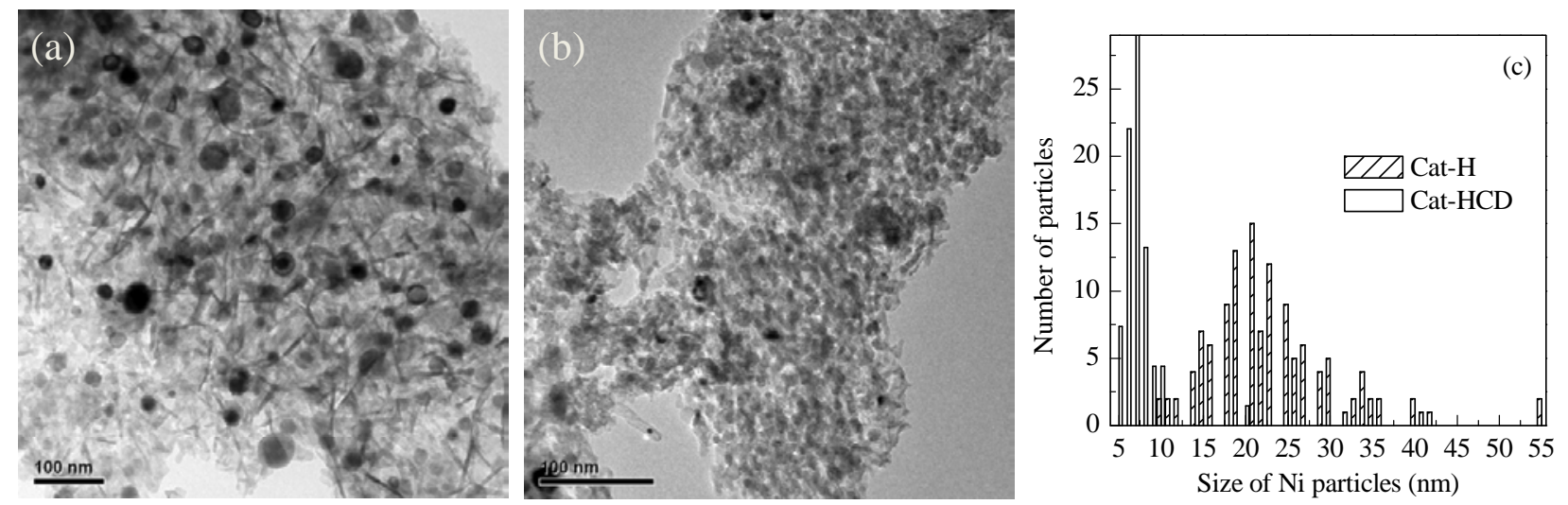

Fig. 4. TEM images and metal particle size distribution of spent catalyst samples pretreated using different routes after reaction for $27 \mathrm{~h}$. (a) TEM of Cat-H; (b) TEM of Cat-HCD; (c) Metal particle size distribution. 


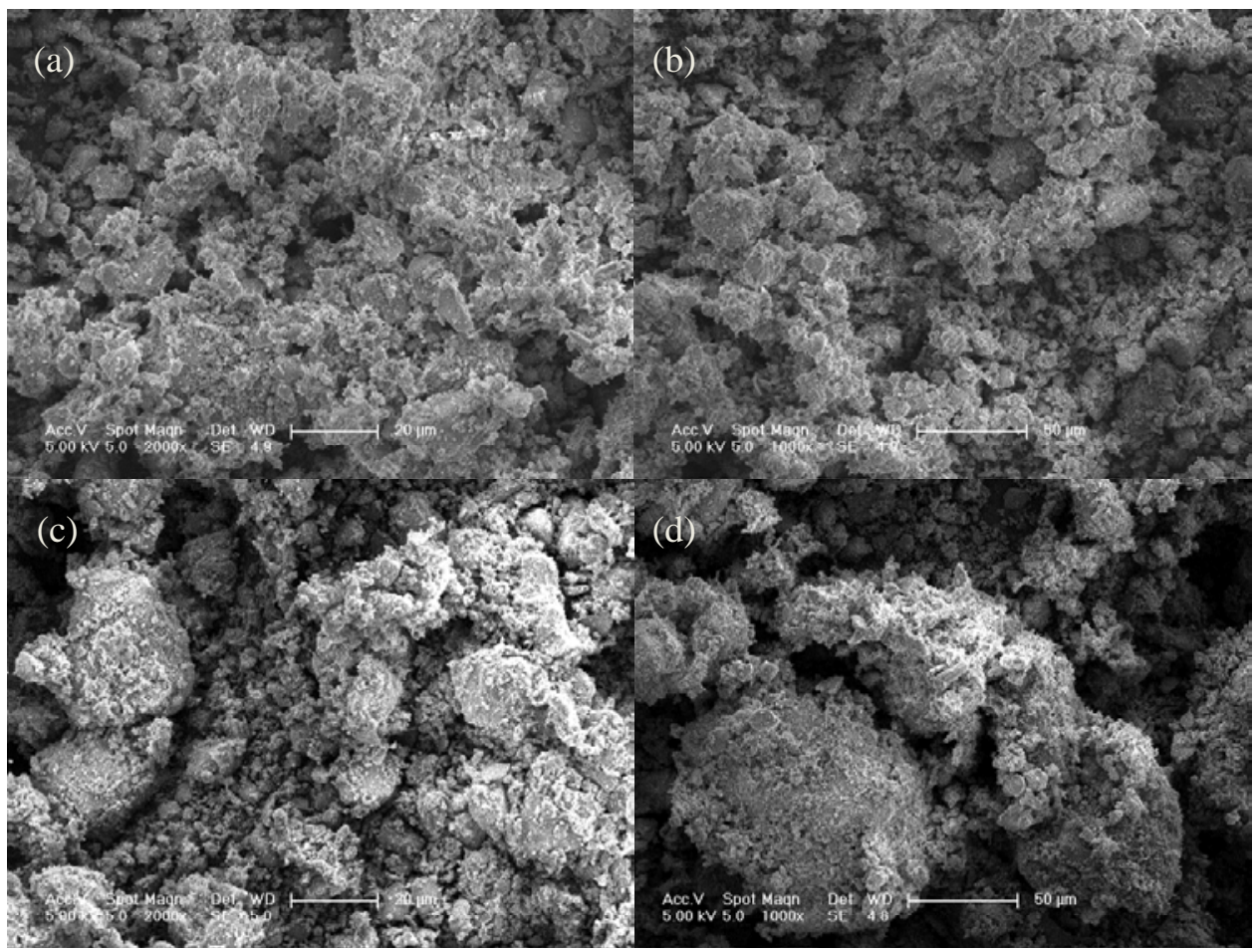

Fig. 6. SEM photographs of catalysts pretreated using different routes after reaction for 27 h. (a, b) Cat-HCD ; (c, d) Cat-H.

caused by the oxidation of amorphous carbon (such as encapsulated carbon), and the second peak at $650{ }^{\circ} \mathrm{C}$ is attributed to oxidation of inert carbon $[9,26]$. It is suggested that a good relationship exists between the quantity of amorphous carbon species and the catalytic activity, and inert carbon is responsible for deactivation of the catalyst during CDRM [27]. It is also found that the $y$-axis span of the second peak in Fig. 5(a) is significantly larger than that in Fig. 5(b), which illustrates that Cat-H produces more inert carbon than Cat-HCD does. The average carbon deposition rates are shown in Table 1. It can be observed that the amount of deposited carbon on Cat-HCD, which is responsible for catalyst deactivation, is much smaller than that on Cat-H. This clearly shows that the new pretreatment caused the improvement in activity and carbon formation tolerance of the catalyst. These results are supported by the XRD patterns, in which the diffraction peak assigned to graphitic carbon was obvious in Cat-H.

\subsubsection{SEM-EDX results}

The SEM photographs and the EDX analysis results for the spent catalyst samples after reaction for $27 \mathrm{~h}$ are shown in Fig. 6 and Table 2, respectively. Larger metal particle clusters are observed in Cat-H than in Cat-HCD. In addition, Fig. 6(c) and (d)

Table 2

Relative standard deviations in, and average metal contents of, used $\mathrm{Ni}-\mathrm{Co} / \mathrm{La}_{2} \mathrm{O}_{3}-\mathrm{Al}_{2} \mathrm{O}_{3}$ catalysts pretreated using different routes.

\begin{tabular}{lccccccc}
\hline \multirow{2}{*}{ Sample } & \multicolumn{3}{c}{$\begin{array}{c}\text { Relative standard } \\
\text { deviation (\%) }\end{array}$} & & \multicolumn{3}{c}{$\begin{array}{c}\text { Average metal } \\
\text { content (\%) }\end{array}$} \\
\cline { 2 - 4 } \cline { 6 - 8 } & $\mathrm{Ni}$ & $\mathrm{Co}$ & $\mathrm{La}$ & & $\mathrm{Ni}$ & $\mathrm{Co}$ & $\mathrm{La}$ \\
\hline Cat-HCD & 13.92 & 11.69 & 11.26 & & 6.49 & 2.82 & 4.76 \\
Cat-H & 27.76 & 24.50 & 22.12 & & 6.36 & 2.84 & 4.77 \\
\hline
\end{tabular}

show carbon filaments deposited over the catalyst surface, which was confirmed by the TG-DSC results. This shows that deposited carbon occupied the catalytic sites, leading to a decline in activity and aggravating sintering of the metal particles [28]. Indeed, the relative standard deviations of the amounts of metals in Cat-HCD are much smaller than those in Cat-H, for almost equivalent average metal contents (Table 2). This confirms that the new pretreatment can retard sintering to maintain a uniform and relatively small size during the reaction. This is in agreement with the TEM and XRD results.

\subsection{Durability results}

Figure 7 presents the durability test results for Cat-HCD. The conversion of $\mathrm{CH}_{4}$ and $\mathrm{CO}_{2}$ tends to be stable from the be-

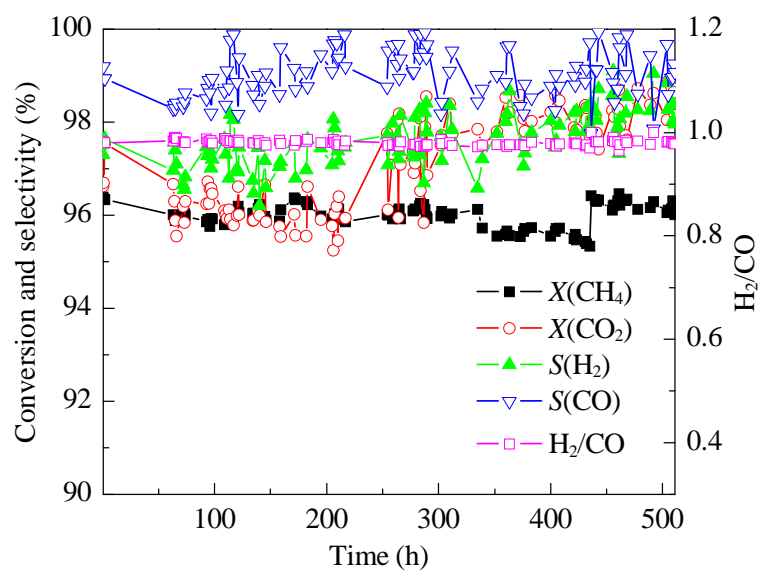

Fig. 7. Durability testing of Cat-HCD. Reaction conditions: $850{ }^{\circ} \mathrm{C}, 0.1$ $\mathrm{MPa}$, gas hourly space velocity $=6000 \mathrm{~mL} \mathrm{~g}_{\mathrm{cat}^{-1}} \mathrm{~h}^{-1}, \mathrm{CH}_{4} / \mathrm{CO}_{2}=1$. 
ginning. The conversion of $\mathrm{CO}_{2}$ is higher than that of $\mathrm{CH}_{4}$, which may be caused by occurrence of the reverse water gas shift reaction, causing the $\mathrm{H}_{2} / \mathrm{CO}$ ratio to be less than unity [29]. High selectivity for both $\mathrm{H}_{2}$ and $\mathrm{CO}$ is observed, and they remain stable during the course of the test. The average conversion of $\mathrm{CH}_{4}$ and $\mathrm{CO}_{2}$, selectivity for $\mathrm{H}_{2}$ and $\mathrm{CO}$, and ratio of $\mathrm{H}_{2} / \mathrm{CO}$ are $96 \%, 97 \%, 98 \%, 99 \%$, and 0.98 , respectively. In addition, the average carbon deposition rate is as low as $0.2 \mathrm{mg}$ $\mathrm{g}_{\mathrm{cat}}{ }^{-1} \mathrm{~h}^{-1}$, which may imply that carbon deposition on the catalyst reached dynamic equilibrium. The results of the durability test suggest that Cat-HCD has high stability.

\section{Conclusions}

$\mathrm{Ni}-\mathrm{Co}$ bimetal supported on $\gamma-\mathrm{Al}_{2} \mathrm{O}_{3}$ pellets for biogas reforming to $\mathrm{H}_{2}$ were successfully synthesized using the excessive impregnation method. The results showed that the catalyst pretreated with both $\mathrm{H}_{2}$ and $\mathrm{CO}_{2}$ showed higher activity, and basically eliminated the long induction period of the biogas reforming reaction, compared with the catalyst pretreated with only $\mathrm{H}_{2}$. In a stability test, Cat-HCD exhibited excellent stability with a very low carbon deposition rate, ca. $0.2 \mathrm{mg} \mathrm{g}_{\mathrm{cat}^{-1}} \mathrm{~h}^{-1}$. The average conversion of $\mathrm{CH}_{4}$ and $\mathrm{CO}_{2}$, selectivity for $\mathrm{H}_{2}$ and $\mathrm{CO}$, and ratio of $\mathrm{H}_{2} / \mathrm{CO}$ were $96 \%, 97 \%, 98 \%, 99 \%$, and 0.98 , respectively. The characterization results revealed that Cat-HCD exhibited higher carbon formation resistance and better anti-sintering performance during reactions, which resulted in smaller metal particles and thus enhanced the stability of the catalyst. These results suggest that the new pretreatment route is very promising for enhancing the performance of biogas reforming catalyst.

\section{Acknowledgements}

The authors thank Mr. Yijian Lai and Miss Yan Xu for their work on TEM and XRD analyses, respectively.

\section{References}

[1] Pinilla J L, Moliner R, Suelves I, Lázaro M J, Echegoyen Y, Palacios J M. Int J Hydrogen Energy, 2007, 32: 4821

[2] Vanherle J, Membrez Y, Bucheli C. J Power Sources, 2004, 127: 300

[3] Tang S, Ji L, Lin J, Zeng H C, Tan K L, Li K. J Catal, 2000, 194: 424

[4] Nagaoka K, Takanabe K, Aika K-i. Chem Commun, 2002: 1006

[5] Ruckenstein E, Wang H Y.J Catal, 2002, 205: 289

[6] Moradi G R, Khosravian F, Rahmanzadeh M. Chin J Catal (催化学 报), 2012, 33: 797

[7] Lombardi L, Carnevale E, Corti A. Energy, 2006, 31: 3208

[8] Hirose T, Ozawa Y, Nagai M. Chin J Catal (催化学报), 2011, 32: 771

[9] Seo H O, Sim J K, Kim K D, Kim Y D, Lim D C, Kim S H. Appl Catal A, 2013, 451: 43

[10] Zhang W D, Liu B S, Zhu C, Tian Y L. Appl Catal A, 2005, 292: 138

[11] Rostrup-Nielsen J R. Stud Surf Sci Catal, 1988, 36: 73

[12] Zhang J G, Wang H, Dalai A K. Appl Catal A, 2008, 339: 121

[13] Green M L H, Xiao T C (肖天存). CN Patent 1541139 A. 2004

[14] Husserl J J, Junge Plug Vatican Velen M J, Koser R. CN Patent 101796 166A. 2010

[15] Kroll V C H, Swaan H M, Lacombe S, Mirodatos C. J Catal, 1996, 164: 387

[16] Zhang Z L, Verykios X E. J Chem Soc, Chem Commun, 1995: 71

[17] Solymosi F. J Mol Catal, 1991, 65: 337

[18] Benito M, García S, Ferreira-Aparicio P, García Serrano L, Daza L. J Power Sources, 2007, 169: 177

[19] Slagtern A, Olsbye U, Blom R, Dahl I M, Fjellvag H. Appl Catal A, 1997, 165: 379

[20] Tomishige K, Chen Y G, Fujimoto K. J Catal, 1999, 181: 91

[21] Nagaoka K, Seshan K, Aika K-i, Lercher J A.J Catal, 2001, 197: 34

[22] Xu J K, Li Z J, Wang J H, Zhou W, Ma J X. Acta Phys-Chim Sin (物理化 学学报), 2009, 25: 253

[23] Patterson A L. Phys Rev, 1939, 56: 978

[24] Zhang J G, Wang H, Dalai A K. J Catal, 2007, 249: 300

[25] Wang S B, Lu G Q. Appl Catal B, 1998, 19: 267

[26] Luo J Z, Yu Z L, Ng C F, Au C T. J Catal, 2000, 194: 198

[27] Chen Y G, Tomishige K, Fujirnoto K. Appl Catal A, 1997, 161: L11

[28] Matsukata M, Matsushita T, Ueyama K. Energy Fuels, 1995, 9: 822

[29] Bradford M C J, Vannice M A. Appl Catal A, 1996, 142: 97

\section{Graphical Abstract}

Chin. J. Catal., 2013, 34: 1826-1832 doi: 10.1016/S1872-2067(12)60648-2

Effects of pretreatment on performance and structure of $\mathrm{Ni}$-Co bimetallic catalyst for biogas reforming to hydrogen

Jian Zhao, Wei Zhou*, Jianxin Ma

East China University of Science and Technology; Tongji University

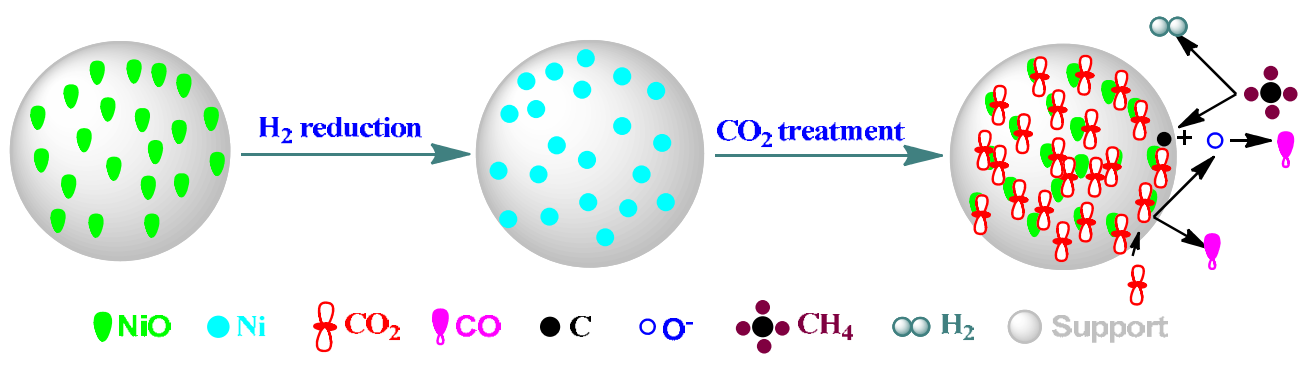

A novel pretreatment route, using both $\mathrm{H}_{2}$ and $\mathrm{CO}_{2}$, for a Ni-Co bimetallic biogas reforming catalyst was designed. The new route significantly improved the performance of the catalyst and basically eliminated the long induction period. The carbon deposition resisitance, anti-sintering ability, and stability of the catalyst were also enhanced by the pretreatment. 


\title{
预处理对Ni-Co双金属沼气重整催化剂性能与结构的影响
}

\author{
赵 健 ${ }^{\mathrm{a}, \mathrm{b}}$, 周 伟 ${ }^{\mathrm{b}, \mathrm{c}, *}$, 马建新 ${ }^{\mathrm{a}, \mathrm{b}, \mathrm{c}}$ \\ a华东理工大学资源与环境工程学院, 上海200237 \\ $\mathrm{b}$ 同济大学新能源汽车工程中心, 上海201804; \\ '同济大学汽车学院, 上海201804
}

摘要: 采用过量浸渍法制备了 $\mathrm{Ni}-\mathrm{Co} / \mathrm{La}_{2} \mathrm{O}_{3}-\gamma-\mathrm{Al}_{2} \mathrm{O}_{3}$ 双金属催化剂, 并使用固定床石英反应器在 $850{ }^{\circ} \mathrm{C}, 0.1 \mathrm{MPa}$ 和空速为 6000 $\mathrm{mL} \mathrm{g}_{\mathrm{cat}}{ }^{-1} \mathrm{~h}^{-1}$ 的条件下考察了预处理对催化剂性能的影响. 运用X射线衍射、热重-差示扫描量热、透射电子显微镜、扫描电镜和 $\mathrm{X}$ 射线能谱分析等手段对催化剂进行了表征. 结果表明, 与传统氢气还原预处理相比, 经氢气和二氧化碳预处理后, 催化剂性能 明显提高, 且能基本消除该催化剂上沼气重整反应的诱导期. $511 \mathrm{~h}$ 的稳定性实验结果表明, 催化剂经氢气和二氧化碳预处理后具 有很好的稳定性和抗积碳性, 平均积碳速率仅为 $0.2 \mathrm{mg} \mathrm{g}_{\mathrm{cat}}{ }^{-1} \mathrm{~h}^{-1}$. 表征结果显示, 经氢气和二氧化碳预处理后, 催化剂具有更好的 抗烧结和抗积碳性能, 反应后金属颗粒较小, 分布较均匀, 粒径分布范围较窄, 从而增强了催化剂的稳定性.

关键词: 预处理; 镍钴催化剂; 沼气重整; 抗积碳性能; 制氢

收稿日期: 2013-04-24. 接受日期: 2013-06-19. 出版日期: 2013-10-20.

*通讯联系人. 电话: (021)69583720; 传真: (021)69583850; 电子信箱: wzhou@tongji.edu.cn

基金来源：科技部国际合作项目(2010DFA64080); 国家高技术研究发展计划(863计划, 2011AA11A275).

本文的英文电子版由Elsevier出版社在ScienceDirect上出版(http://www.sciencedirect.com/science/journal/18722067). 